\title{
Invasion potential of herbaceous ornamental perennials in northern climate conditions
}

\author{
Timo Kaukoranta ${ }^{1}$, Sirkka Juhanojaㄹ ${ }^{2}$, Eeva-Maria Tuhkanen ${ }^{2}$ and Terho Hyvönen ${ }^{1}$ \\ ${ }^{1}$ Natural Resources Institute Finland (Luke), Tietotie 4, Fl-31600 Jokioinen, Finland \\ ${ }^{2}$ Natural Resources Institute Finland (Luke), Itäinen pitkäkatu 4 A, 20520 Turku, Finland \\ e-mail: terho.hyvonen@luke.fi
}

\begin{abstract}
Ornamental plants comprise a great share of alien plant species worldwide. In northern regions, harsh climate conditions limit their invasiveness. We studied invasion potential of perennial herbaceous ornamental plants in Finland (between 60 and $65^{\circ} \mathrm{N}$ ) by using species ranking based on their reproduction success as an indicator. Data were collected from four-year common garden and moisture-controlled field experiments which were completed with germination tests of seeds in a greenhouse. Altogether, 220 clones from 166 species were included in the studies. In common gardens, $50 \%$ of the species were found to produce seedlings and $75 \%$ rhizomes, respectively. Twelve of the clones produced neither seedlings nor rhizomes. Rankings of the invasion potential based on the two reproduction modes did not correlate. The species known for their invasion potential in temperate or cool climates appeared to be among the highest ranking seedling producers in the common gardens. In the field experiment, the highest seedling production (73\%) was found in the semi-dry moisture regime, followed by the dry (40\%) and the moist (27\%) regimes. In the greenhouse experiment, $83 \%$ of the studied clones and $84 \%$ of the species emerged. Temperature sum required for the production of viable seeds for one third of the studied species is reached at least every second year in latitudes $62-63^{\circ} \mathrm{N}$. Several perennial herbaceous ornamentals have a potential for northward range expansion.
\end{abstract}

Key words: alien species, Finland, garden plants, invasive plants, species distribution

\section{Introduction}

In search for new ornamental species, alien species have long been widely introduced outside their native ranges. The wide and repeated introductions increase the likelihood of them escaping from cultivation (Dehnen-Schmutz et al. 2007a, 2007b, Hanspach et al. 2008, Ööpik et al. 2013). Thus, it is not surprising that ornamental plants comprise of a great share of alien plant species worldwide. For example, 17\% of alien plant species in Europe (Lambdon et al. 2008) and around $70 \%$ of weeds in Australia have been imported for gardening (Virtue et al. 2004). Also in northern regions the share of ornamentals of introduced plants is high ranging from over half of the vascular plants regarded as problem species in Norway (Gederaas et al. 2012), 74\% of 232 naturalized alien species in Estonia (Ööpik et al. 2008) to 18 out of 23 invasive species in Finland (MMM 2012).

Ornamentals have been selected for rapid and often vigorous growth, large size, long flowering time, tolerance of competition and survival in physically and biologically adverse environments. These traits also characterize successful alien invasive plant species (Klironomos 2002, Lake and Leishman 2004, Anderson et al. 2006, Colautti et al. 2006, Pyšek and Richardson 2007, Hanspach et al. 2008, Küster et al. 2008, Fenesi and Botta-Dukát 2010, van Kleunen et al. 2010). Species traits, that generally are not actively selected for in perennial ornamentals, but have been associated with invasiveness in several studies, are the abundant production of seed and rapid germination (Callaway and Josselyn 1992, Pérez-Fernández et al. 2000, Goergen and Daehler 2001, van Kleunen and Johnson 2007, Küster et al. 2008, Perglová et al. 2009, Schlaepfer et al. 2010, Chrobock et al. 2011). Seed production is not a prerequisite for a species to escape from cultivation, which is shown by the fact that some of the globally worst invasive terrestrial plant species, such as Arundo donax L. (Saltonstall et al. 2010) and Fallopia japonica (Houtt.) Ronse Decr. (Engler et al. 2011, Bailey et al. 2009, Weber 2003), propagate rarely by seed in invaded regions. This may facilitate the invasion of perennial ornamentals in northern regions where harsh climate conditions limit seed production.

A necessary precondition for a species to survive and become naturalized is climatic match with the source and target regions (see however Milbau and Stout 2008). The match is more likely for species that tolerate a wide range of climates and often predicts naturalization and consequent invasion (Goodwin et al. 1999, Thuiller et al. 2005, Hanspach et al. 2008, Pyšek et al. 2009, Alexander et al. 2011, Dostál et al. 2013), though not in all target areas (Milbau and Stout 2008). Climate matching has usually been studied by modelling (e.g. Thuiller et al. 2005, Araújo 
and Peterson 2012), which provide information on potentially suitable climate conditions in new regions. However, actual reproduction success must be studied by field experiments. For high latitude and cool climates data for comparison of the relationship between the invasiveness and reproduction of ornamental plants is sparse.

In this study, we used data from experiments that were planned for testing hardiness of a wide range of herbaceous ornamental perennials at northern edge of their range. Useful metrics that were observed were establishment of new seedlings and rhizomes in open air and emergence of seedlings in the greenhouse. Our goals were 1 ) to assess the proportion of species that can reproduce by seed among those that can survive over winter, 2) to assess their effectiveness for producing viable seeds and seedlings and 3 ) based on reproduction success in the climates of the experimental sites, to identify the species that have the highest potential for spreading to the boreal climate zone. We expected the majority of the species to succeed in the sexual reproduction since the plant species represented herbaceous perennial ornamentals that had been found to tolerate cold winters, spring frosts, and short growing seasons (Tuhkanen and Juhanoja 2010). However, reproduction could be also confounded by other factors that were not systematically recorded: pests and diseases or short day requirement (19-22 hours day-length in the study region), self-incompatibility or sterility.

\section{Methods}

\section{Plant material and experiments}

The data consisted of observations on seedling and rhizome production in (1) common garden experiments in five cities, (2) a field experiment with controlled minimum soil moisture, and (3) a greenhouse test of emergence rate and germination speed of seeds collected from the field experiment. In the cities and in the field experiment, observations were made in 2006-2010. These three types of data sources represented different geographic scales and measurement accuracies. The common gardens covered a wide climatic range and many years, but the observations were only semi-quantitative. In the moisture-controlled field experiment, quantitative observations were made over years. The greenhouse experiment allowed accurate, repeated observations. Using the experimental data, each clones' potential geographic ranges of reproduction by seed were assessed by mapping over Finland and Baltic Sea region temperature sums (ETS) of recent climate and comparing it with the ETS values the clones required for the production of viable seed in the experiments.

Originally, the experimental planning aimed at finding hardy perennials that require low maintenance and have high ornamental value. The perennials were vigorous wild types that have not been intensively bred. They were expected to compete effectively for space by being either tall and large plant types, or effectively vertically spreading types. Where several origins were available for a species, the clones obtained from southern nurseries were used in the northern experimental sites. However, even the southern experimental sites can be considered to be high in the north $\left(60\right.$ to $\left.64^{\circ} \mathrm{N}\right)$ relative to the original growing areas of non-native species.

Rooted cuttings for planting were obtained from six Finnish commercial nurseries, some from botanical gardens of the Universities of Helsinki, Joensuu, Oulu and Turku, and a few from private collections (Juhanoja and Lukkala 2008). Altogether 220 clones from 166 species were included in the study (Table 1, Appendix 1).

Table 1. Number of species and clones observed in common gardens, in moisture controlled field experiment and in greenhouse experiment

\begin{tabular}{|c|c|c|c|c|c|c|c|}
\hline & & & & & \multicolumn{3}{|c|}{ Status } \\
\hline Experiment & Location & $\begin{array}{l}\text { Irrigation } \\
\text { threshold }\end{array}$ & $\begin{array}{c}\text { No of } \\
\text { species }\end{array}$ & $\begin{array}{l}\text { No of } \\
\text { clones }\end{array}$ & Native & $\begin{array}{l}\text { Alien found } \\
\text { in Finland }\end{array}$ & $\begin{array}{l}\text { Alien not found } \\
\text { in Finland }\end{array}$ \\
\hline \multirow[t]{5}{*}{ Common garden } & Helsinki & & 112 & 117 & 18 & 37 & 61 \\
\hline & Tampere & & 39 & 41 & 4 & 18 & 19 \\
\hline & Turku & & 69 & 73 & 14 & 19 & 40 \\
\hline & Kuopio & & 38 & 41 & 5 & 16 & 20 \\
\hline & Oulu & & 69 & 72 & 9 & 23 & 39 \\
\hline \multirow[t]{3}{*}{ Field experiment } & Piikkiö & -100 & 52 & 61 & 7 & 22 & 31 \\
\hline & & -150 & 83 & 96 & 12 & 29 & 54 \\
\hline & & -200 & 70 & 82 & 11 & 27 & 43 \\
\hline Greenhouse & Piikkiö & & 79 & 84 & 9 & 29 & 44 \\
\hline
\end{tabular}


Nineteen species were native to Finland and 37 were aliens reportedly growing in Finland, the others have been grown or tested in parks and gardens but not reported to have spread to landscape (Lampinen et al. 2012). Three species - Solidago canadensis L., Fallopia japonica and Vinca minor L. - that are considered invasive in Finland (MMM 2012), the Baltic Sea region or climatically nearly analogous areas of North America (Global Invasive Species Database 2014, EPPO 2019, Invasive Plant Atlas of the United States 2014, National Invasive Species Information Center 2014, DAISIE European Invasive Alien Species Gateway 2014, NOBANIS 2019) were included in the experiments.

\section{Common garden experiments}

Experiments were established in 2005 in five city areas: Oulu $\left(65^{\circ} 01^{\prime} \mathrm{N}, 25^{\circ} 28^{\prime} \mathrm{E}\right)$ (four sites), Kuopio $\left(62^{\circ} 53^{\prime} \mathrm{N}\right.$, $27^{\circ} 40^{\prime \prime} \mathrm{E}$ ) (two sites), Tampere $\left(61^{\circ} 29^{\prime} \mathrm{N}, 023^{\circ} 45^{\prime} \mathrm{E}\right)$ (three sites), Turku $\left(60^{\circ} 27^{\prime} \mathrm{N}, 022^{\circ} 16^{\prime} \mathrm{E}\right)$ (one site), and Helsinki $\left(60^{\circ} 10^{\prime} \mathrm{N}, 024^{\circ} 56^{\prime} \mathrm{E}\right)$ with its adjacent cities Espoo, Vantaa and Kerava (23 sites) (Fig. 1). Rooted cuttings were planted in 1373 observations plots. All species were not tested in all sites and all cities, and the species composition for each site was selected for expected tolerance to local climate and site type (park, cemetery, shade, sun).

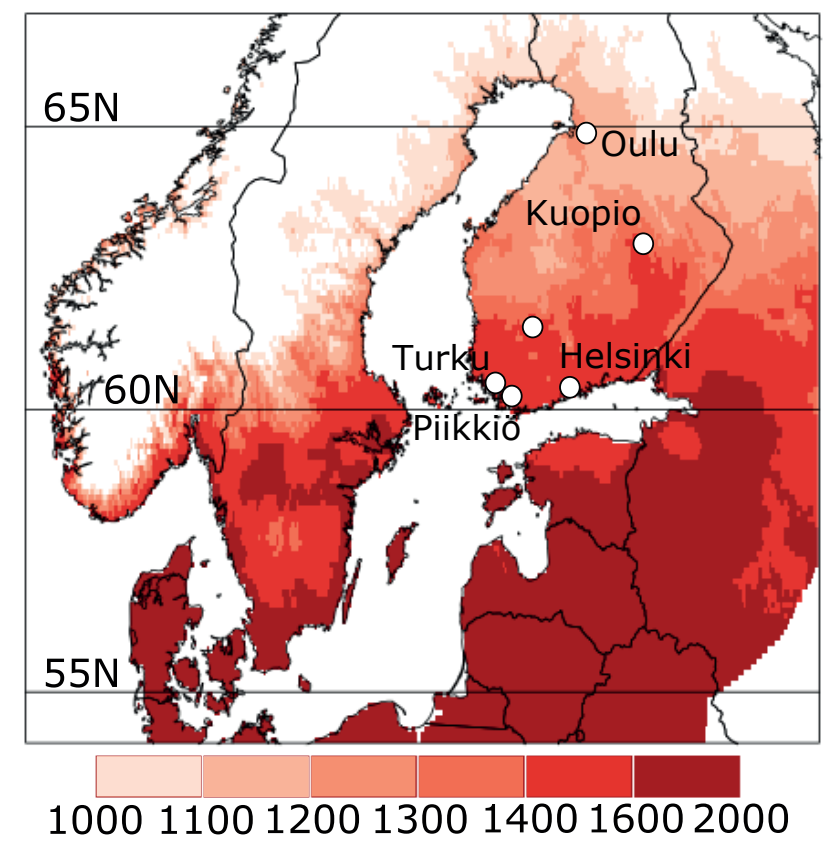

Fig. 1. Median of degree-days (ETS) 1999-2018 (base temperature $5^{\circ} \mathrm{C}$ )

In the common gardens, the size of the planted areas varied from about $10 \mathrm{~m}^{2}$ to over $100 \mathrm{~m}^{2}$. Their shapes were adjusted to match planting sites. A homogenous, weed free $30-50 \mathrm{~cm}$ thick soil bed (Kekkilän perennamulta, Kekkilä, Tuusula, Finland; pH 6, organic matter 14\%, nitrogen-phosphorus-potassium 100-2-100 mg kg-1 of dry matter) was used at all sites. In early spring, withered plants were cut back and plant residues were mostly left to serve as a source of nutrients (Juhanoja and Lukkala 2008).

Starting one year after planting, reproduction of the clones by seed and rhizomes or runners was scored early in September in 2006-2010. The scale was (0) no, (1) 1-5, (2) >5 seedlings per $\mathrm{m}^{2}$ emerged or rhizomes produced. Though at each site the clones were planted in several plots, only one seedling and one rhizome score were recorded for each clone and site in each year.

To get a largely comparable selection of species for every city, the data were pooled over observation sites and years in each city by calculating means and maximums of the scores for each species in a city. Thus, in further analysis there was one observation for the seedling emergence and one observation for the rhizome production for each species in a city. The clones were ranked in each city both by the scores of the seedling emergence and the rhizome production.

In each city, (1) Pearson correlation was used for testing for the association of the mean and maximum scores of the seedling emergence/ rhizome production. (2) Consistency of the results over the cities was tested by computing 
correlations between the cities: mean/max seedling emerge and min/max rhizome production. (3) Kendall's tau-b correlation was applied for testing for the association of the status of alien species (not found in Finland by 2012 / alien found in Finland) with mean score of seedling emergence. The correlation was computed for all clones and for the clones which had maximum seedling emergence scores greater than 0.2 .

\section{Moisture-controlled field experiment}

An experiment with similar objectives as the common garden experiment was established in Piikkiö $\left(60^{\circ} 23^{\prime} \mathrm{N}\right.$, $22^{\circ} 33^{\prime} \mathrm{E}$ ) with 108 clones representing 95 species (Juhanoja and Lukkala 2008). In contrast to the common garden experiment, the soil moisture was accurately controlled and observations on seedling emergence were quantitative.

Three soil moisture regimes were set up to provide optimal conditions for plant species adapted to moist, semi-dry or dry conditions with irrigation thresholds $-100,-150,-200 \mathrm{hPa}$, respectively. Each regime was divided in three blocks to create three replicates of the plots. A plot of one square meter for a clone consisted of a double row of two to 16 plants, depending on the expected final size of plants. Pathways between the rows were covered with hardwood chips. Soil bed was made of 30-50 cm thick layer of weed free soil mixture (Kekkilän perennamulta, Kekkilä, Tuusula, Finland). Plants were grown in full sunlight, except shade requiring species that were covered by a green screen that reduced radiation by $50 \%$ (Juhanoja and Tuhkanen 2010, Juhanoja and Tuhkanen 2013, Tuhkanen and Juhanoja 2010, 2013). Soil moistures were monitored by tensiometers and maintained by drip irrigation.

Observations on seedling emergence were made in 2006-2010. Most seedlings emerged and could be scored only in the first two or three years after planting when the canopies were not yet fully closed. Seedlings that had emerged during a growing season were removed in late autumn, they were identified and their numbers counted. The experiment was continued until 2012 when seeds were collected for a greenhouse experiment. Abundance of seed production by the clones was assessed qualitatively on the following percentage scale: $0,25,50,75,100$.

The clones were ranked by the number of seedlings per plot $\left(1 \mathrm{~m}^{2}\right)$. The rank orders of the clones were compared pair-wise by computing least square differences of the rank orders with proc GLM of the SAS statistical software. Rankings of the soil moisture regimes were compared using Kendall's tau-b correlation. In each regime-pair comparison, only the clones that existed in both regimes were included.

\section{Emergence rate and germination speed experiment in greenhouse}

A greenhouse experiment was conducted to assess the capacity of clones for producing viable seed and to estimate their germination rate. Seeds were collected in the moisture controlled field experiment in 2012 after a cool, rainy growing season. The season lasted 183 days above $5^{\circ} \mathrm{C}$ and had an effective temperature sum (ETS) of 1385 degree-days (dd) with a base temperature $5^{\circ} \mathrm{C}$. Seeds were stored in paper bags at $5{ }^{\circ} \mathrm{C}$ until sowing into the greenhouse from mid-December to mid-March. Seeds of each clone were sown in four one-litre pots containing half a litre of soil mixture (Kekkilän perennamulta, Kekkilä, Tuusula, Finland). The pots were irrigated three times a week from above. Heating, ventilation and shading screen were used for controlling air temperature. It was allowed to freely fluctuate between $10^{\circ} \mathrm{C}$ and $25^{\circ} \mathrm{C}$, which corresponds approximately to mid-latitude climate from spring to autumn in Western Europe.

Seedling emergence was observed over 221 days after the sowing (d.a.s.), first every couple of days, then weekly and the end biweekly. From the data were computed final emergence at 221 d.a.s. (FE221) and durations from sowing to $1 \%(D 1 d), 10 \%(D 10 d)$ and $30 \%$ (D30d).

Transformation SQRT(FE221+0.5) was applied to stabilize variance of FE221 and then significance of pair-wise least square differences (LSD) of FE221 were computed with proc GLM of SAS statistical software. Significance ( $p$ $<0.05$ ) of pair-wise LSD of D10d and D30d were computed with proc GENMOD of SAS statistical software using gamma distribution with inverse (power(-1)) link function. All clones were tested pair-wise despite this leading to post-hoc testing. Association for emergence speed and final emergence was analyzed by computing Pearson correlations between the final emergence and D10d and D30d.

The clones were ranked by their ability to produce seedlings in the common gardens and controlled moisture experiment to five groups. The groups were assigned coefficients $0,25,50,75$, and 100 that reflected the abundance of seed production (ASP). ASP and FE221 were used to get a qualitative measure of the potential for spread by seed $($ PSeed): PSeed $=$ ASP $\times$ FE221. The clones in the experiments were ranked by PSeed, but their differences were not tested statistically. 


\section{Comparing experiments}

The clonal compositions of the three experiment types were partially overlapping. Of the clones in the common garden experiment $49 \%$ and $38 \%$ were included in the moisture controlled and greenhouse experiment, respectively. $41 \%$ of the clones in the greenhouse experiment were included in the moisture controlled experiment.

To test the similarity of species rankings in different types of experiments, Kendall's tau-b rank correlation was applied. When comparing experiments, only the clones present in all compared experiments were included in the analyses: (1) Experiments in the common gardens were compared with each other for the rank of mean and maximum score of seedling emergence, (2) Common gardens (rank of maximum score of seedling emergence) were compared with the moisture controlled field experiment (rank of number of seedlings per square meter), (3) The greenhouse experiment (FE221 and PSeed) was compared with the common garden experiments (rank of maximum score of seedling emergence) and (4) with the moisture controlled field experiment (rank of number of seedlings per square meter).

\section{Geographic range of seed production limited by ETS}

To estimate potential geographic range of spread by seed as limited by warmness of summer in the Baltic Sea region, ETS requirements for the seedling emergence and production of viable seed were compared with the median ETS in the region. For the experimental sites ETS above a base temperature of $5{ }^{\circ} \mathrm{C}$ was computed using daily gridded temperature data 2005-2010 from Finnish Meteorological Institute (FMI), except for the Piikkiö field where data from a FMI weather station located in the field. In the common garden experiment and in the moisture experiment, it was not known in which year the seeds that gave rise to seedlings had grown. Therefore, the highest ETS value of the three years preceding an observation of a seedling emergence was attached to that observation. For the clones tested in the Piikkiö greenhouse in 2013, exact ETS was known because the seeds had been collected in 2012. The median ETS for years $1999-2018$ was mapped using gridded (0.1 resolution) daily mean temperature from E-OBS v. 19.0e dataset (Cornes et al. 2018).

\section{Results \\ Reproduction by seeds and rhizomes in common gardens}

The majority of the species and clones tested in common gardens produced seedlings in Helsinki, about half of species in three cities, and a third of species in Kuopio (Table 2). In all cities about half of the species and clones produced rhizomes. Over all of the gardens, $60 \%$ of the clones and $50 \%$ of the species were found to produce seedlings, and $73 \%$ and $75 \%$ rhizomes, respectively (Appendix 1). Twelve of the clones were observed to produce neither seedlings nor rhizomes. The maximum seedling emergence scores were moderately and significantly correlated between all cities, except ranks in Turku with the ranks in the inland cities of Kuopio and Tampere (Table 3). The mean and maximum scores of the seedling emergence in each city were strongly related, having significant Pearson correlation coefficients above 0.9 (result not shown).

Table 2. Percentage of species and clones that were found to produce seedlings and rhizomes in common gardens and moisture controlled field experiment. In greenhouse experiment percentage of species and clones that emerged during 221 days after sowing.

\begin{tabular}{|c|c|c|c|c|c|c|}
\hline \multirow[b]{2}{*}{ Experiment } & \multirow[b]{2}{*}{ Location } & \multirow[b]{2}{*}{$\begin{array}{l}\text { Irrigation } \\
\text { threshold }\end{array}$} & \multicolumn{2}{|c|}{ Seedlings (\%) } & \multicolumn{2}{|c|}{ Rhizomes (\%) } \\
\hline & & & Species & Clones & Species & Clones \\
\hline \multirow[t]{5}{*}{ Common garden } & Helsinki & & 59 & 77 & 55 & 51 \\
\hline & Tampere & & 46 & 41 & 54 & 50 \\
\hline & Turku & & 45 & 29 & 54 & 53 \\
\hline & Kuopio & & 32 & 22 & 48 & 44 \\
\hline & Oulu & & 49 & 47 & 54 & 51 \\
\hline \multirow[t]{3}{*}{ Field ${ }^{1}$ experiment } & Piikkiö & -100 & 27 & 33 & - & - \\
\hline & & -150 & 73 & 73 & - & - \\
\hline & & -200 & 40 & 44 & - & - \\
\hline Greenhouse & Piikkiö & & 84 & 83 & - & - \\
\hline
\end{tabular}

${ }^{1)}$ Seedlings and rhizomes were not separated. 
Table 3. Kendall's tau-b correlations of maximum scores in common garden experiments among cities

\begin{tabular}{lccccc}
\hline & & Helsinki & Tampere & Turku & Kuopio \\
\hline Tampere & tau-b & 0.33 & - & - & - \\
& $p$ & 0.015 & - & - & - \\
Turku & $\mathrm{N}$ & 35 & - & - & - \\
& tau-b & 0.35 & 0.40 & - & - \\
& $p$ & 0.001 & 0.037 & - & - \\
Kuopio & $\mathrm{N}$ & 62 & 22 & 0.07 & - \\
& tau-b & 0.42 & 0.25 & 0.656 & - \\
& $p$ & 0.003 & 0.294 & 30 & 0.44 \\
Oulu & $\mathrm{N}$ & 37 & 15 & 0.39 & 0.018 \\
& tau-b & 0.31 & 0.46 & 0.002 & 23 \\
\hline$p=$ probability of tau-b differing from $0 ; \mathrm{N}=$ number of clone pairs in correlation test &
\end{tabular}

The native species Alchemilla alpinus L., Lythrum salicaria L. and Malva moschata L. and non-natives Alchemilla mollis (Buser) Rothm., Heliopsis helianthoides L. var scabra (Dun.) Fern., Hyssopus officinalis L., Salvia nemorosa L., Telekia speciosa (Schreb.) Baumg., and Verbena hastata L. had abundant seedling production most regularly (Appendix 2). The rank correlations of all alien clones (alien not found vs. found in Finland) and the clones which had maximum seedling emergence scores greater than 0.2 (alien not found vs. found in Finland, clone emergence score $>0.2$ ) with the maximum seedling emergence were not significant (result not shown),

To test whether the status effect would be found among the alien clones that produced seedlings at least moderately, the correlation was computed for the clones which had maximum seedling emergence scores greater than 0.2. Again, the status was not found to be significantly correlated with the emergence (result not shown).

The most efficient rhizome producers were not good seedling producers. This can be seen in Table 4, where mean rank of seedling emergence (S rank) is shown in parallel with the rhizome production scores. However, the correlations of the city-wise mean/max rhizome production with the mean/max of the seedling emergence were not statistically significant. The mean rank of seedling emergence was computed by averaging the city-wise ranks of the clones.

\section{Reproduction in field experiment}

In all moisture regimes, about $70 \%$ of 105 clones and species produced seedlings (Appendix 1). The highest seedling production (73\%) was found in in the semi-dry moisture regime ( $-150 \mathrm{hPa}$ irrigation threshold), followed by dry $(-200 \mathrm{hPa})$ and moist regimes $(-100 \mathrm{hPa})$ (Table 2). Fourteen clones started flowering in August or September, which was too late for seeds to mature. The clonal rankings in the dry regime were correlated with the rankings in semi-dry regimes irrigation threshold) every year. Whereas the rankings in the moist regime were not correlated with the rankings in the other regimes (results not shown).

Comparisons of species can be done on plot area basis but not on per planted plant basis because the number of plants planted was not equal for all species. Solidago canadensis 'Goldkind' was among the highest seedling producers in all soil moisture regimes (Table 5), whereas 'Leraft' did not produce any seedlings. Alien Anaphalis margaritacea performed well in all regimes and aliens Heliopsis helianthoides, Inula helenium L. and Telekia speciosa were among the ten highest ranking seedling producers in the two regimes with the highest soil moisture $(-100,-150 \mathrm{hPa})$.

\section{Emergency rate and germination speed in greenhouse}

The overall seed germination rate was high in the greenhouse experiment: $83 \%$ of the studied clones and $84 \%$ of the species emerged in the experiment (Table 2, Appendix 1). 18-19\% of the clones and species had at least $30 \%$ emergence within 35 d.a.s. (Table 6). Emergence rate was mostly stable within each clone, as indicated by the fact that the durations from sowing to $1 \%$ (D1d), $10 \%$ (D10d), and 30\% (D30d) emergence were highly and significantly correlated (results not shown). The emergence speed was not related to the final cumulative emergence at 221 d.a.s. (FE221), which was shown by low, non-significant Pearson correlations of FE221 with D1d, D10d, and D30d (results not shown). 
The fastest to emerge and also the ones which had the greatest potential for spread by seed (PSeed) were Dianthus deltoides L. 'Leuchtfunk', Aconogonon divaricatum (L.) Nakai ex Mori, Solidago canadensis 'Goldkind' and Cerastium Tomentosum L. var. columnae Silberteppich.

Seven out of eight native species had low emergence rate. An exception was a non-native cultivar 'Leuchtfunk' of Dianthus deltoides. The group of alien species found (42 clones) and not found (32 clones) in Finland did not essentially differ in emergence speed and final emergence rate. Their mean D1d and mean FE221 were $53 \mathrm{~d} / 23 \%$ and $47 \mathrm{~d} / 24 \%$, respectively. Their mean PSeed and mean rank by PSeed were 1218 / 60 and 1751 / 65, respectively.

Table 4. Mean rhizome production in common garden experiments in 2006-2010. In the righthand column, the S rank is the mean of common garden maximum ranks of seedling emergence. Means were calculated over cities. Fifteen clones ranked highest by rhizome production or having a mean score higher than 0.5 in any garden are shown. Below are also results for other clones that are considered potentially invasive (MMM 2012). Clones are sorted by mean rank of rhizome production over cities. Cities where clones were not tested are marked by dash.

\begin{tabular}{|c|c|c|c|c|c|c|}
\hline Species or clone & Helsinki & Tampere & Turku & Kuopio & Oulu & S rank \\
\hline Echinops ritro & 0.48 & - & - & - & - & $>87$ \\
\hline Geranium macrorrhizum & 0.50 & - & 0.78 & - & 0.13 & 66 \\
\hline Vinca minor & 0.50 & - & 0.00 & - & 0.88 & $>87$ \\
\hline Lamium galeobdolon 'Florentinum' & - & - & 0.48 & - & 0.35 & 87 \\
\hline Hosta Tarhafunkia 'Ginko Craig' & 0.25 & - & 0.63 & 0.27 & - & 38 \\
\hline Euphorbia palustris & 0.38 & - & - & - & - & 65 \\
\hline Veronica austriaca ssp. teucrium ,Königsblau' & 0.33 & 0.38 & - & - & 0.38 & 35 \\
\hline Bistorta officinalis & 0.12 & - & 0.68 & 0.00 & 0.50 & 81 \\
\hline Agastache 'Blue Fortune' & 0.00 & - & - & 0.80 & 0.17 & 59 \\
\hline Hosta sieboldiana 'Elegans' & 0.32 & - & - & - & - & $>87$ \\
\hline Monarda didyma 'Scorpion' & - & - & - & - & 0.31 & 61 \\
\hline Epimedium $x$ youngianum & - & 0.31 & - & - & - & $>87$ \\
\hline Hosta Fortunei 'Hyacinthina' & 0.00 & - & 0.50 & 0.41 & - & 39 \\
\hline Calamagrostis $x$ acutifolia 'Karl Foerster' & 0.30 & - & - & - & - & $>87$ \\
\hline Saponaria ocymoides & - & - & - & - & 0.30 & $>87$ \\
\hline Cerastium Tomentosum 'Silberteppich' & 0.06 & 0.10 & 0.50 & - & 0.52 & 51 \\
\hline \multicolumn{7}{|l|}{ Known potentially invasive } \\
\hline Solidago canadensis unidentified cultivar & 0.00 & 0.25 & 0.00 & 0.42 & 0.43 & 50 \\
\hline Solidago Canadensis 'Leraft' & - & 0.00 & - & 0.00 & 0.45 & 50 \\
\hline Solidago Canadensis 'Golden Mosa' & 0.10 & - & - & - & - & 50 \\
\hline Fallopia japonica var. compacta & - & - & - & - & 0.02 & $>87$ \\
\hline
\end{tabular}

\section{Comparing experiments}

The rankings of the clones in the common gardens, based on mean score of emergence over 2006-2010, were not consistently correlated with the mean rankings in the moisture controlled field experiment (Table 7). Mostly, the rank correlations were positive but they were at least moderately significant $(p<0.1)$ only in five of the 15 correlation pairs. Telekia speciosa, which was the most successful seedling producer in the common gardens (see Table 3), appeared also in the top ten in the moist and semi-dry regimes in the moisture controlled field experiment (Table 5). Hyssopus officinalis, Euphorbia epithymoides L. and Dracocephalum sibiricum L. that produced well seedlings in the common gardens were in the top ten in the dry and semi-dry regimes in the moisture controlled field experiment. Solidago canadensis, which appeared in the top ten at all moisture regimes in the moisture controlled field experiment (Table 5), produced seedlings in the two warmest common garden sites, Helsinki and Turku.

The rankings of the final emergence 221 d.a.s. (FE221) and the potential for spread by seed (PSeed) derived from the greenhouse germination experiment were not correlated with the rankings of mean seedling emergence in the common garden experiments and the Piikkiö field experiment (Kendall's tau-b correlation, results not shown). 


\begin{tabular}{|c|c|c|c|c|c|}
\hline Year & 2006 & 2007 & 2008 & 2009 & 2010 \\
\hline ETS & 1680 & 1507 & 1397 & 1370 & 1500 \\
\hline \multicolumn{6}{|l|}{ Moist } \\
\hline Euphorbia palustris & 13 & 9 & 2 & 9 & 14 \\
\hline Lythrum salicaria & 20 & 6 & 3 & 2 & 3 \\
\hline Eupatorium maculatum & 0 & 14 & 6 & 2 & 8 \\
\hline Heliopsis helianthoides & 5 & 5 & 3 & 6 & 3 \\
\hline Aruncus dioicus & 0 & 1 & 0 & 10 & 9 \\
\hline Inula helenium & 0 & 1 & 0 & 2 & 7 \\
\hline Solidago canadensis & 4 & 1 & 3 & 0 & 2 \\
\hline Trollius sp. & 2 & 0 & 3 & 1 & 4 \\
\hline Pulmonaria saccharata & 0 & 0 & 2 & 1 & 3 \\
\hline Telekia speciosa & 1 & 0 & 0 & 0 & 5 \\
\hline \multicolumn{6}{|l|}{ Semi-dry } \\
\hline Solidago canadensis & 182 & 94 & 71 & 71 & 126 \\
\hline Achillea millefolium & 30 & 139 & 60 & 36 & 45 \\
\hline Anemonidium canadense & 16 & 0 & 62 & 77 & 109 \\
\hline Malva sp. & 63 & 23 & 18 & 26 & 48 \\
\hline Dracocehalum sibiricum & 71 & 27 & 14 & 39 & 25 \\
\hline Heliopsis helianthoides & 34 & 49 & 28 & 23 & 30 \\
\hline Anaphalis margaritacea & 58 & 9 & 11 & 12 & 27 \\
\hline Telekia speciosa & 15 & 5 & 3 & 20 & 37 \\
\hline Inula helenium & 0 & 14 & 2 & 19 & 38 \\
\hline Eupatorium maculatum & 0 & 15 & 2 & 9 & 35 \\
\hline \multicolumn{6}{|l|}{ Dry } \\
\hline Achillea millefolium & 20 & 27 & 32 & 30 & 34 \\
\hline Anaphalis margaritacea & 24 & 6 & 10 & 31 & 19 \\
\hline Solidago canadensis & 16 & 7 & 16 & 18 & 29 \\
\hline Malva sp. & 10 & 3 & 8 & 19 & 22 \\
\hline Hyssopus officinalis & 14 & 2 & 6 & 8 & 10 \\
\hline Artemisia pontica & 15 & 0 & 9 & 7 & 0 \\
\hline Armeria maritima & 9 & 3 & 2 & 3 & 7 \\
\hline Euphorbia polychroma & 0 & 0 & 1 & 6 & 13 \\
\hline Veronica prostrata & 1 & 0 & 2 & 2 & 15 \\
\hline Veronica virginica & 2 & 0 & 3 & 4 & 5 \\
\hline
\end{tabular}

ETS= effective temperature sum $\left(5^{\circ} \mathrm{C}\right.$ threshold) of seasons 2006 to 2010

\section{Geographic range of seed production limited by ETS}

For the production of viable seed ETS of 1220-1385 dd appeared to be enough for most clones. Forty-four clones tested in the common gardens were able to produce viable seed with 1300-1400 dd (result not shown). ETS for the 15 highest ranked clones from Appendix 2 is presented in Table 8. The $1300-1400$ dd is reached at least every second year up to the latitude $62^{\circ} \mathrm{N}$ in western Finland, and up to $63^{\circ} \mathrm{N}$ in eastern Finland (Fig. 1). Every four years this ETS occurs approximately $1.5^{\circ}$ higher in the north (results not shown). 


\section{AGRICULTURAL AND FOOD SCIENCE}

T. Kaukoranta et al. (2019) 28: 45-57

Table 6. Germination of the seeds in the germination experiment. Duration in days from sowing to $10 \%$ emergence (D10d) and to $30 \%$ emergence (D30d), final emergence 221 days after sowing (FE221), seed production abundance (ASP) and potential for spread by seed (PSeed (PSeed $=$ FE221 $\times$ S)) in 2013. Species with the same superscripted letter in columns D10d, D30d and FE221 do not differ statistically in post-hoc pair-wise comparison. Fifteen species which had at least $30 \%$ emergence rate in 35 d.a.s. are shown and are ranked by D30d.

\begin{tabular}{lccccc}
\hline Species & D10d & D30d & FE221 & ASP & PSeed \\
\hline Dianthus deltoides 'Leuchtfunk' & $12 \mathrm{a}$ & $12 \mathrm{a}$ & $72 \mathrm{ab}$ & 100 & 7200 \\
Aster conspicuus & $12 \mathrm{a}$ & $12 \mathrm{a}$ & $51 \mathrm{bc}$ & 75 & 3825 \\
Salvia x sylvestris & $22 \mathrm{a}$ & $13 \mathrm{ab}$ & $20 \mathrm{ef}$ & 50 & 1000 \\
Salvia nemorosa & $12 \mathrm{a}$ & $15 \mathrm{ab}$ & $40 \mathrm{~cd}$ & 75 & 3000 \\
Heliopsis helianthoides var. scabra & $12 \mathrm{a}$ & $15 \mathrm{ab}$ & $39 \mathrm{~cd}$ & 50 & 1950 \\
Aconogonon divaricatum & $14 \mathrm{a}$ & $17 \mathrm{ab}$ & $61 \mathrm{~b}$ & 100 & 6100 \\
Helenium hoopesii & $15 \mathrm{a}$ & $18 \mathrm{~b}$ & $36 \mathrm{~cd}$ & 75 & 2700 \\
Aconogonon weyrichii & $15 \mathrm{a}$ & $19 \mathrm{~b}$ & $36 \mathrm{~cd}$ & 75 & 2700 \\
Cerastium tomentosum 'Silberteppich' & $17 \mathrm{a}$ & $21 \mathrm{bc}$ & $50 \mathrm{bc}$ & 75 & 3750 \\
Potentilla megalantha & $20 \mathrm{a}$ & $21 \mathrm{bc}$ & $30 \mathrm{de}$ & 25 & 750 \\
Solidago canadensis 'Goldkind' & $16 \mathrm{a}$ & $22 \mathrm{bc}$ & $61 \mathrm{~b}$ & 100 & 6100 \\
Nepeta subsessilis & $12 \mathrm{a}$ & $30 \mathrm{c}$ & $70 \mathrm{ab}$ & 25 & 1750 \\
Thymus serpyllum & $16 \mathrm{a}$ & $30 \mathrm{c}$ & $37 \mathrm{~cd}$ & 25 & 925 \\
Doronicum orientale & $20 \mathrm{a}$ & $33 \mathrm{~cd}$ & $31 \mathrm{~d}$ & 50 & 1550 \\
Thymus praecox & $20 \mathrm{a}$ & $33 \mathrm{~cd}$ & $13 \mathrm{ef}$ & 25 & 325 \\
\hline
\end{tabular}

Table 7. Kendall's tau-b on mean seedling emergence $\left(1 \mathrm{~m}^{-2}\right)$ in moisture controlled field experiment in dry, semidry and moist blocks with mean scores of seedling emergence each common garden city in 2005-2010

\begin{tabular}{lcccccc}
\hline & & Helsinki & Tampere & Turku & Kuopio & Oulu \\
\hline Piikkiö & tau-b & 0.16704 & -0.08146 & 0.29483 & -0.05103 & 0.36898 \\
Dry block & $\mathrm{P}$ & 0.1961 & 0.6775 & 0.0747 & 0.8504 & 0.0211 \\
& $\mathrm{~N}$ & 37 & 18 & 26 & 11 & 26 \\
Piikkiö & tau-b & 0.17918 & -0.09311 & 0.1328 & 0.35441 & 0.02627 \\
Semi-dry block & $\mathrm{P}$ & 0.0813 & 0.5612 & 0.2922 & 0.0785 & 0.8341 \\
& $\mathrm{~N}$ & 56 & 24 & 39 & 17 & 40 \\
Piikkiö & tau-b & 0.05356 & 0.20612 & 0.11605 & -0.27779 & -0.43202 \\
Moist block & $\mathrm{P}$ & 0.6803 & 0.3385 & 0.4869 & 0.3009 & 0.0116 \\
& $\mathrm{~N}$ & 37 & 15 & 25 & 11 & 25 \\
\hline
\end{tabular}

Table 8. Maximum effective temperature sum (ETS) of the three years preceding occurrence of seedlings in spring or autumn for the 15 highest ranked species and Solidago canadensis. In the Greenhouse (GH) column, ETS is for the species grown in Piikkiö field and tested in greenhouse.

\begin{tabular}{lccccccc}
\hline Species & Helsinki & Tampere & Turku & Kuopio & Oulu & Piikkiö field & GH \\
\hline Telekia speciosa & $1350-1730$ & $1410-1580$ & $1390-1520$ & - & - & $1496-1680$ & 1385 \\
Salvia nemorosa 'Ostfriesland' & $1570-1730$ & $1390-1610$ & - & - & $1220-1380$ & - & 1385 \\
Tellima grandiflora & $1600-1660$ & $1410-1580$ & - & - & $1220-1380$ & 1680 & 1385 \\
Malva moschata & $1570-1650$ & - & $1620-1620$ & $1590-1590$ & $1380-1380$ & - & - \\
Lavatera thuringiaca & $1560-1650$ & - & $1620-1620$ & $1590-1660$ & $1220-1380$ & - & 1385 \\
Verbena hastata 'Rosea' & - & - & $1620-1620$ & - & $1320-1380$ & 1496 & - \\
Sanguisorba officinalis & $1620-1730$ & - & $1520-1620$ & - & $1220-1380$ & 1680 & - \\
Hyssopus officinalis & $1490-1730$ & - & - & - & $1220-1380$ & $1496-1680$ & 1385 \\
Veronica longifolia & $1620-1690$ & - & $1620-1620$ & - & $1220-1380$ & 1507 & - \\
Euphorbia epithymoides & - & $1390-1610$ & - & - & $1220-1320$ & $1507-1680$ & 1385 \\
Geranium platypetalum & - & - & - & - & $1220-1380$ & - & - \\
Alchemilla mollis & $1570-1694$ & $1410-1580$ & $1520-1620$ & $1440-1550$ & $1220-1320$ & $1507-1680$ & 1385 \\
Aconogonon weyrichii & $1510-1730$ & - & - & $1340-1490$ & - & - & 1385 \\
Dianthus deltoides & $1530-1730$ & - & - & - & - & $1496-1680$ & 1385 \\
Dracocephalum sibiricum & $1640-1640$ & - & $1490-1620$ & $1590-1590$ & $1380-1380$ & $1507-1680$ & - \\
Solidago canadensis & $1350-17301$ & - & $1390-15201$ & - & - & $1496-16801$ & 13852 \\
\hline Cultivar: ${ }^{1}$ Unspecified, ${ }^{2}$ Goldkind & & & & & & & -
\end{tabular}




\section{Discussion}

As expected, the majority of the species included in the study were found to be capable of producing viable seeds or rhizomes in the northern climate conditions. While the common garden experiments showed mostly similar rankings for the full set of the clones for all cities, the three different types of experiments gave different rankings for the set of clones that were common for all experiments. Most of the species, which are reported to be invasive in some regions with cool climate, reproduced better by seed than the rest of species.

One reason for the success in the reproduction of the species may lie in the species selection. The studied species represent about $30 \%$ of the 500 species of herbaceous perennial ornamentals that are currently listed in Finnish nursery catalogues. The species selected for the study had the basic requirement of being vigorous and apparently winter hardy. Very few died in winter within two years without producing seedlings or rhizomes. A majority, $61 \%$ of the species could produce seedlings in the common gardens when effective temperature sum (ETS) was 1220-1730 dd, and 84\% of the species produced viable seed at the climatically mildest site (Piikkiö) with 1385 dd. Based on the observed ETS in the experiments, about one third of all tested species would be able to reproduce by seed at least every second year up to latitudes $62-63^{\circ} \mathrm{N}$ and every four years up to $63.5-64^{\circ} \mathrm{N}$. These findings indicate potential for the northward range expansion of the studied species, which will be further enhanced by warming climate (Hyvönen et al. 2012).

Twelve of the clones were found neither to produce seedlings nor spread by rhizomes in common gardens. Six of these clones were included in other experiments and was found to produce seedlings, which indicates sub-optimal moisture or temperature conditions or seedling death caused by pest or diseases. Seed production of some species may also have been limited by day-length (Saikkonen et al. 2012). Long days in the outdoor experiments, maximally 19-22 hours, may have delayed the onset of flowering of day-length sensitive species too much for seed maturation to succeed. Further, pollinators of insect-pollinated species may have been absent at flowering time, and some clones could be sterile due to genetic hindrances (Müller-Schärer et al. 2004). These factors are also likely causes for the divergent results between the experiments regarding all species.

The species known for their invasion potential in temperate or cool climates appeared to be among the highest ranking seedling producers in the common gardens. Seven clones ranked in the top 40 seedling producers had earlier been reported to be invasive or potentially invasive in some region with cool climate, whereas among the rest of 128 clones there were two invasive species that did not produce seedlings or viable seed: Vinca minor and Fallopia japonica. They both use rhizomes for spreading (Weber 2003). F. japonica established new plants but it was ranked low for rhizome spread among the species, whereas $V$. minor spread rapidly in soil beds. $V$. minor is locally invasive in the Baltic States (NOBANIS 2014) and North-Western USA (Invasive Plant Atlas of the United States 2019) and potentially invasive in Finland where it has competed out other shrubs in a deciduous forest area in the south-western coast of Finland. Most of the alien species that were ranked high for their reproduction have not yet established widely in Finland. A possible reason is that most of the studied species have been introduced in Finland very recently, in the last 30-60 years. A longer exposure time is expected to increase the likelihood of the escape (Dehnen-Schmutz et al. 2007a, 2007b, Pyšek et al. 2009).

Another known successful invasive species, Solidago canadensis, ranked high in seedling production also our experiments. However, the success appeared partly to be dependent on the cultivar. 'Goldkind' was a very good seedling producer in the common gardens and emerged very rapidly in the greenhouse, but 'Leraft' produced sterile seed in the moisture-controlled field experiment. Furthermore, S. canadensis spreads well by rhizomes, too. In common gardens, it was among the most efficient rhizome producers at latitudes 63 and $65^{\circ} \mathrm{N}$. For these reasons, S. canadensis is invasive in temperate and cool climates in Europe and Asia (Zwölfer 1976, Dong et al. 2006). In Finland, it has commonly escaped from gardens, mainly below the latitude $62^{\circ} \mathrm{N}$ and along the Baltic Sea coast up to the latitude $65^{\circ} \mathrm{N}$ (Lampinen et al. 2012).

Among other alien species, the common garden and moisture controlled field experiments brought Telekia speciosa to the top. It produced seedlings in moist and semi-dry soil but not in dry soil in the moisture controlled experiment with 1370-1680 dd. Though, the greenhouse germination experiment showed that seeds grown in $1385 \mathrm{dd}$ had low viability, which indicates that current climate is not yet optimal for rapid spread of $T$. speciosa. In Denmark, with milder oceanic climate, it is classified as highly invasive (EPPO 2019, DAISIE European Invasive Alien Species Gateway 2019). In Norway, it is considered to have high invasion potential but not expected to have significant ecological impact (Gederaas et al. 2012). The recent spread of T. speciosa in the Central European mountains by seed (Zająz and Zająz 2009, Pyšek et al. 2012, Zelnik 2012) and spread in Central Russia (Notov et al. 2011), naturalization in Finland, and its capacity for seedling emergence in the experiments indicate that it can spread further in Finland in warmer years. 
The findings of our study showed that numerous herbaceous ornamental perennials are capable of producing viable seeds or rhizomes at high latitudes. Previous studies have shown seed production to be associated with invasion success (Callaway and Josselyn 1992, Pérez-Fernández et al. 2000, Goergen and Daehler 2001, Hamilton et al. 2005, van Kleunen and Johnson 2007, Küster et al. 2008, Perglová et al. 2009, Schlaepfer et al. 2010, Chrobock et al. 2011). Regarding perennials, rhizome production alone can be enough for successful invasion (Bailey et al. 2009). The two reproduction modes enhance the success of perennials in northern regions since seed production is more easily limited by harsh climate. Therefore, perennial ornamentals have a high invasion potential also in northern regions.

\section{Acknowledgements}

This work is based on the work done under the project "Increasing knowledge on invasive alien species (IAS) in Finland - distribution, dispersal, risk management, pathways for entry", which has been supported by Finnish Ministry of Agriculture and Forestry.

We acknowledge the E-OBS dataset from the EU-FP6 project UERRA (http://www.uerra.eu) and the Copernicus Climate Change Service, and the data providers in the ECA\&D project (https://www.ecad.eu).

\section{References}

Alexander, J.M., Kueffer, C., Daehler, C.C., Edward, P.J., Pauchard, A., Seipel T. \& MIREN Consortium 2011. Assembly of nonnative floras along elevational gradients explained by directional ecological filtering. Proceedings of the National Academy of Sciences 108: 656-661. https://doi.org/10.1073/pnas.1013136108

Anderson, N.O., Galatowitsch, S.M. \& Gomez, N. 2006. Selection strategies to reduce the invasive potential in introduced plants. Euphytica 148: 203-216. https://doi.org/10.1007/s10681-006-5951-7

Araújo, M.B. \& Peterson, T. 2012. Uses and misuses of bioclimatic envelope modeling. Ecology 93: 1527-1539. https://doi. org/10.1890/11-1930.1

Bailey, J.P., Bimova, K. \& Mandak, B. 2009. Asexual spread versus sexual reproduction and evolution in Japanese Knotweed s.I. sets the stage for the "Battle of the Clones". Biological Invasions 11: 1189-1203. https://doi.org/10.1007/s10530-008-9381-4

Callaway, J.C. \& Josselyn, M.N. 1992. The introduction and spread of smooth cordgrass (Spartina alterniflora) in South San Francisco Bay. Estuaries 15: 218-226. https://doi.org/10.2307/1352695

Chrobock, T. \& Kempel, A. Fischer, M. \& van Kleunen, M. 2011. Introduction bias: Cultivated alien plant species germinate faster and more abundantly than native species in Switzerland. Basic Applied Ecology 12: 244-250. https://doi.org/10.1016/j.baae.2011.03.001

Colautti, R.I., Grigorovich, I.A. \& Maclsaac, H.J. 2006. Propagule pressure: a null model for biological invasions. Biological Invasions 8: 1023-1037. https://doi.org/10.1007/s10530-005-3735-y

Cornes, R., van der Schrier, G., van den Besselaar, E.J.M. \& Jones, P.D. 2018: An Ensemble Version of the E-OBS Temperature and Precipitation Datasets. Journal of Geophysical Research Atmospheres: 123. https://doi.org/10.1029/2017JD028200

DAISIE European Invasive Alien Species Gateway 2019. www.europe-aliens.org. Accessed 15 March 2019.

Dehnen-Schmutz, K., Touza, J., Perrings, C. \& Williamson, M. 2007a. A century of the ornamental plant trade and its impact on invasion success. Diversity and Distributions 13: 527-534. https://doi.org/10.1111/j.1472-4642.2007.00359.x

Dehnen-Schmutz, K., Touza, J., Perrings, C. \& Williamson, M. 2007b. The horticultural trade and ornamental plant invasions in Britain. Conservation Biology 21: 224-231. https://doi.org/10.1111/j.1523-1739.2006.00538.x

Dong, M., Lu, J.Z., Zhang, W.J., Chen, J.K. \& Li, B. 2006. Canada goldenrod (Solidago canadensis): an invasive alien weed rapidly spreading in China. Acta Phytotaxonomica Sinica 44: 72-85. https://doi.org/10.1360/aps050068

Dostál, P., Dawson, W., van Kleunen, M., Keser, L.H. \& Fischer M. 2013. Central European plant species from more productive habitats are more invasive at a global scale. Global Ecology and Biogeography 22: 64-72. https://doi.org/10.1111/j.1466-8238.2011.00754.x

Engler, J., Abt, K. \& Buhk, C. 2011. Seed characteristics and germination limitations in the highly invasive Fallopia japonica s.I. (Polygonaceae). Ecolocigal Research 26: 555-562. https://doi.org/10.1007/s11284-011-0813-8

EPPO 2019. EPPO Lists of Invasive Alien Plants. www.eppo.int. Accessed 15 March 2019.

Fenesi, A. \& Botta-Dukát, Z. 2010. Do short-lived and long-lived alien plant species differ regarding the traits associated with their success in the introduced range? Biological Invasions 12: 611-623. https://doi.org/10.1007/s10530-009-9468-6

Gederaas, L., Moen, T.L., Skjelseth, S. \& Larsen, L.K. 2012. Alien species in Norway-with the Norwegian Black List 2012. The Norwegian Biodiversity Information Centre, Norway. https://artsdatabanken.no/Files/13960/Alien_Species_in_Norway_-_with_the_ Norwegian_Black_List_2012

Global Invasive Species Database 2019. http://www.iucngisd.org/gisd. Accessed 15 March 2019.

Goergen, E. \& Daehler, C.C. 2001. Reproductive ecology of a native Hawaiian grass (Hetropogon contortus; Poaceae) versus its invasive alien competitor (Pennisetum setaceum; Poaceae). International Journal of Plant Science 162: 317-326. https://doi. org/10.1086/319587 
Goodwin, B.J., McAllister, A.J. \& Fahrig, J. 1999. Predicting invasiveness of plant species based on biological information. Conservation Biology 13: 422-426. https://doi.org/10.1046/j.1523-1739.1999.013002422.x

Hanspach, J., Kühn, I., Pyšek, P., Boos, E. \& Klotz, S. 2008. Correlates of naturalization and occupancy of introduced ornamentals in Germany. Perspectives in Plant Ecology, Evolution and Systematics 10: 241-250. https://doi.org/10.1016/j.ppees.2008.05.001

Hamilton, M.A., Murray, B.R., Cadotte, M.W., Hose, G.C., Baker, A.C., Harris, C.J. \& Licari, D. 2005. Life-history correlates of plant invasiveness at regional and continental scales. Ecology Letters 8: 1066-1074. https://doi.org/10.1111/j.1461-0248.2005.00809.x

Hyvönen, T., Luoto, M. \& Uotila, P. 2012. Assessment of weed establishment risk in a changing European climate. Agricultural and Food Science 21: 348-360. https://doi.org/10.23986/afsci.6321

Invasive Plant Atlas of the United States 2019. www.invasiveplantatlas.org. Accessed 15 March 2019.

Juhanoja, S. \& Lukkala, R. 2008. Julkisten alueiden perennat: Väliraportti hankkeesta 'Julkisten alueiden perennakasvustojen perustamis- ja hoitotekniikat sekä kestävien perennojen valinta' vuosilta 2005-2007. (Herbaceous perennials for urban areas) MTT:n selvityksiä 157. 123 p. http://www.mtt.fi/mtts/pdf/mtts157.pdf

Juhanoja, S. \& Tuhkanen, E.M. 2010. Herbaceous perennials for urban landscaping in Finland. In: Prosdocimi Gianquinto, G. \& Orsini F. (eds). Proceedings of the second international conference on landscaping and urban horticulture: volume 1. Bologna, Italy, June 9-13, 2009. Acta Horticulturae 881: 263-269. https://doi.org/10.17660/ActaHortic.2010.881.35

Juhanoja, S. \& Tuhkanen, E.M. 2013. Improving the quality of landscaping plants in Finland: the combination of field and landscape trials. In Cockshull K.E., David J.C. \& Whitehouse C.M. (eds). Proceedings of First International Trials Conference: Assessment of Ornamental Plants. Wisley, United Kingdom. July 4-7, 2011. Acta Horticulturae 980: 87-94. https://doi.org/10.17660/ ActaHortic.2013.980.11

van Kleunen, M., Weber, E. \& Fischer, M. 2010. A meta-analysis of trait differences between invasive and non-invasive plant species. Ecology Letters 13: 235-245. https://doi.org/10.1111/j.1461-0248.2009.01418.x

van Kleunen, M. \& Johnson, S.D. 2007. South African Iridaceae with rapid and profuse seedling emergence are more likely to become naturalized in other regions. Journal of Ecology 95: 674-681. https://doi.org/10.1111/j.1365-2745.2007.01250.x

Klironomos, J.N. 2002. Feedback with soil biota contributes to plant rarity and invasiveness in communities. Nature 417: 67-70. https://doi.org/10.1038/417067a

Küster, E.C., Kühn, I., Bruelheide, H. \& Klotz, S. 2008. Trait interactions help explain plant invasion success in the German flora. Journal of Ecology 96: 860-868. https://doi.org/10.1111/j.1365-2745.2008.01406.x

Lake, J.C. \& Leishman, M.R. 2004. Invasion success of exotic plants in natural ecosystems: The role of disturbance, plant attributes and freedom from herbivores. Biological Conservation 117: 215-226. https://doi.org/10.1016/S0006-3207(03)00294-5

Lambdon, P.W., Pyšek, P., Basnou, C., Hejda, M., Arianoutsou, M., Essl, F., Jarošík, V., Pergl, J., Winter, M., Anastasiu, P., Andriopoulos, P., Bazos, I., Brundu, G., Celesti-Grapow, L., Chassot, P., Delipetrou, P., Josefsson, M., Kark, S., Klotz, S., Kokkoris, Y., Kühn, I., Marchante, H., Perglová, I., Pino, J., Vilà, M., Zikos, A., Roy, D. \& Hulme, P.E. 2008. Alien flora of Europe: species diversity, temporal trends, geographical patterns and research needs. Preslia 80: 101-149.

Lampinen, R., Lahti, T. \& Heikkinen, M. 2012. Kasviatlas 2011. Helsingin Yliopisto, Luonnontieteellinen keskusmuseo, Helsinki. http://koivu.luomus.fi/kasviatlas/

Milbau, A. \& Stout, J.C. 2008. Factors Associated with Alien Plants Transitioning from Casual, to Naturalized, to Invasive. Conservation Biology 22: 308-317. https://doi.org/10.1111/j.1523-1739.2007.00877.x

MMM 2012. Kansallinen vieraslajistrategia (Finland's National Strategy on Invasive Alien Species) Ministry of Agriculture and Forestry, Helsinki. https://www.vieraslajit.fi/fi/content/finlands-national-strategy-invasive-alien-species

Müller-Schärer, H., Schaffner, U. \& Steinger, T. 2004. Evolution in invasive plants: implications for biological control. Trends in Ecology \& Evolution 19:417-422. https://doi.org/10.1016/j.tree.2004.05.010

National Invasive Species Information Center 2019. http://www.invasivespeciesinfo.gov. Accessed 15 March 2019.

NOBANIS 2019. North European and Baltic network on invasive species. www.nobanis.org. Accessed 15 March 2019.

Notov, A.A., Vinogradova, Y.K. \& Mayorov, S.R. 2010. On the problem of development and management of regional black books. Russian Journal of Biological Invasions 2: 35-45. https://doi.org/10.1134/S2075111711010061

Ööpik, M., Bunce, R.G.H. \& Tischler, M. 2013. Horticultural markets promote alien species invasions: an Estonian case study of herbaceous perennials. NeoBiota 17: 19-37. https://doi.org/10.3897/neobiota.17.4217

Ööpik M., Kukk T., Kull, K. \& Kull, T. 2008. The importance of human mediation in species establishment: analysis of alien flora of Estonia. Boreal Environmental Research 13(A): 53-67.

Pérez-Fernández, M.A., Lamont, B.B., Marwick, A.L. \& Lamont, W.G. 2000. Germination of seven exotic weeds and seven native species in south-western Australia under steady and fluctuating water supply. Acta Oecologica 21: 323-336. https://doi. org/10.1016/j.actao.2009.06.007

Perglová, I., Pergl, J., Skálov, H., Moravcová, L., Jarošík, V. \& Pyšek, P. 2009. Differences in germination and seedling establishment of alien and native Impatiens species. Preslia 81: 357-375. http://www.preslia.cz/P094Perglova.pdf

Pyšek, P. \& Richardson, D.M. 2007. Traits associated with invasiveness in alien plants: Where do we stand? In: Nentwig, W. (ed.). Biological invasions. Berlin: Springer-Verlag. Ecological Studies 193: 97-125. https://doi.org/10.1007/978-3-540-36920-2_7

Pyšek, P., Jarošík, V., Pergl, J., Randall, R., Chytrý, M., Kühn, I., Tichý, L., Danihelka, J., Chrtekjun, J. \& Sádlo, J. 2009. The global invasion success of Central European plants is related to distribution characteristics in their native range and species traits. Diversity and Distribution 15: 891-903. https://doi.org/10.1111/j.1472-4642.2009.00602.x

Pyšek, P., Danihelka, J., Sádlo, J., Chrtek, J.Jr, Chytrý, M., Jarošík, V., Kaplan, Z., Krahulec, F., Moravcová, L., Pergl, J., Štajerová, K. \& Tichý, L. 2012. Catalogue of alien plants of the Czech Republic (2nd edition): checklist update, taxonomic diversity and invasion patterns. Preslia 84: 155-255. http://www.preslia.cz/P122Pysek.pdf 
Saikkonen, K., Taulavuori, K., Hyvönen, T., Gundel, P., Hamilton, C., Vänninen, I., Nissinen, A. \& Helander, M. 2012. Climate changedriven species' range shifts filtered by photoperiodism. Nature Climate Change 2: 239-242. https://doi.org/10.1038/nclimate1430

Saltonstall K., Lambert A. \& Meyerson L.A. 2010. Genetics and reproduction of common (Phragmites australis) and giant reed (Arundo donax). Invasive Plant Science and Management 3: 495-505. https://doi.org/10.1614/IPSM-09-053.1

Schlaepfer, D.R., Glättli, M., Fischer, M. \& van Kleunen, M. 2010. A multi-species experiment in their native range indicates preadaptation of invasive alien plant species. New Phytologist 185: 1087-1099. https://doi.org/10.1111/j.1469-8137.2009.03114.x

Thuiller, W., Richardson, D.M., Pyšek, P., Midgley, G.F., Hughes, G.O. \& Rouge, M. 2005. Niche-based modeling as a tool for predicting the risk of alien plant invasions at a global scale. Global Change Biology 11: 2234-2250. https://doi.org/10.1111/j.13652486.2005.001018.x

Tuhkanen, E.M. \& Juhanoja, S. 2010. Clonal selection of herbaceous perennials for northern urban areas. In: Prosdocimi Gianquinto, G. \& Orsini, F. (eds.). Proceedings of Second International Conference on Landscape and Urban horticulture: vol. 1. Bologna, Italy. June 9-13, 2009. Acta Horticulturae 881: 251-255. https://doi.org/10.17660/ActaHortic.2010.881.33

Tuhkanen, E.M. \& Juhanoja, S. 2013. Observation methods in the clonal selection of herbaceous perennials. In: Cockshull K.E., David J.C. \& Whitehouse C.M. (eds.). Proceedings of First International Trials Conference: Assessment of Ornamental Plants. Wisley, United Kingdom. July 4-7, 2011. Acta Horticulturae 980: 79-85. https://doi.org/10.17660/ActaHortic.2013.980.10

Virtue, J.G., Bennett, S.J. \& Randall, R.P. 2004. Plant introductions in Australia: how can we resolve 'weedy'conflicts of interest. In: Sindel, B.M. \& Johnson S.B. (eds.). Proceedings of the 14th Australian Weeds Conference. p. 42-48.

Weber, E. 2003. Invasive Plant Species of the World. A Reference Guide to Environmental Weeds. Oxon: CABI Publishing. 560 p.

Zająz, M. \& Zająz, A. 2009. Apohytes as invasive plants in the vegetation of Poland. Biodiversity research and conservation 15: 35-40. https://doi.org/10.2478/v10119-009-0015-1

Zelnik, I. 2012. The presence of invasive alien species in different habitats: case study from Slovenia. Acta biologica slovenica 55 : 25-38. http://www.ckff.si/javno/zbirka/ABS_55-2_Zelnik\%202012.pdf

Zwölfer, H. 1976. The goldenrod problem: possibilities for a biological weed control project in Europe. EPPO Publications Series B 81: 9-18. 